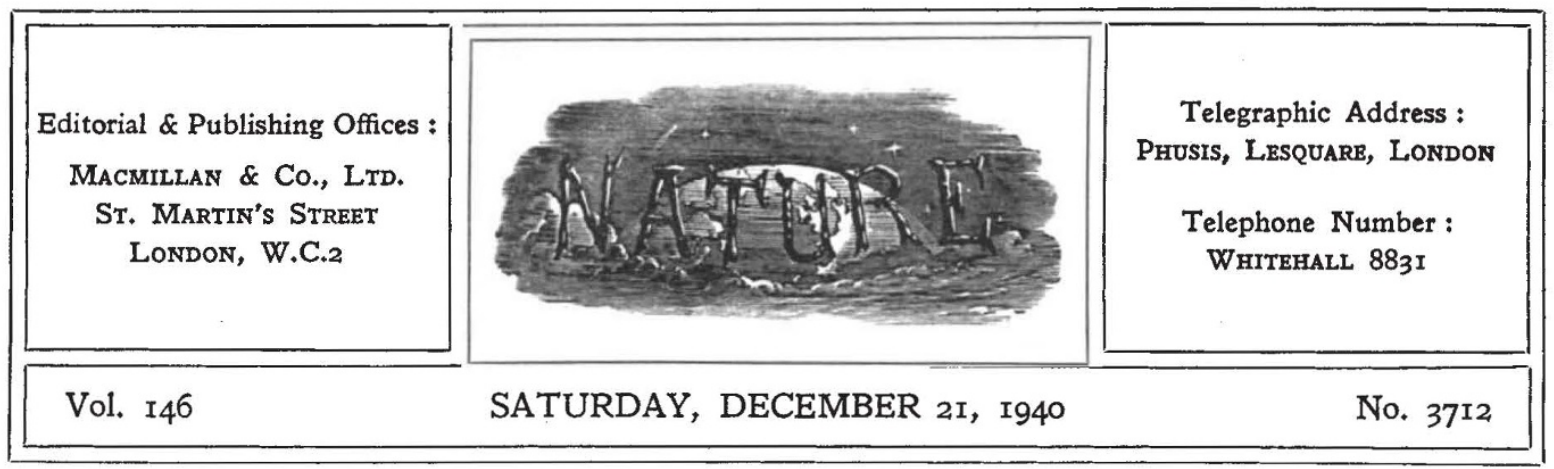

\title{
FOOD SUPPLIES AND THE BLOCKADE
}

$\mathrm{T}$ HE fact that there was a serious food shortage in Germany towards the end of the War of 1914-18 makes people more ready to believe rumours that already in this War the shortage of food in Germany and in German-occupied countries is so serious that it may soon paralyse the Nazi war effort. These rumours should be received with caution. In the two or three years before the outbreak of the present War, there were numerous statements suggesting that food shortage, financial difficulties and other internal troubles were acute and that there were signs of a breakdown in the economic system which would bring about the collapse of the Nazi regime.

Whatever the origin of these rumours, their effect was to deceive the world about the real military strength of Germany. In view of the suggestion that, on humanitarian grounds, the blockade should be relaxed to allow food to reach the people in occupied countries, it is of interest to review what happened in the War of 1914-18 and consider whether events in the present War will follow the same course, as many people are too ready to assume.

The Germans fostered the belief that their defeat in the last War was caused by the starvation of the civilian population through the Allied food blockade. The idea that the defeat of the German Army was due to the blockade on food was assiduously cultivated in Germany as a means of getting the people to believe that the Army had not really been defeated. The food blockade certainly helped. But its main help was probably in reducing the output of munitions, owing to the deterioration of the health of the workpeople. The German Army was at full fighting efficiency in the summer of 1918. The Hindenburg line was broken and the Army defeated because the accession of men and armaments from the United States had, for the first time in the War, made the military forces of the Allies superior to those of the Germans.

Nor as a matter of fact was the blockade the sole, or even the main, cause of the acute shortage of food in Germany. In the five-year period before 1914, Germany produced 80 per cent of the food she consumed. The blockade was never complete. Germany continued to receive food from neutral countries in Europe. The deficit due to the blockade might have been made good by increased home-production, saving in wastage and efficient distribution. The consumption of food in Germany among the civilian population fell not by 20 per cent, which would have been the fall necessary had there been a complete blockade, but by about 50 per cent. The acute food shortage was due to the sacrifice of food for war ends. Nitrates, which should have been used for fertilizers, were used for making explosives. About two million farm workers were taken from the land for military service or for work in munition factories, and horses were taken from the farms for the Army. Because of the diversion of the national effort from food production to war ends, food production fell. Thus, for example, the yield of grain fell by about 22 per cent and the yield of sugar by nearly 35 per cent.

Further, part of the food that was produced, especially fats and sugar, was used for making explosives. Consumption of fat fell from the prewar level of $12 \frac{1}{2} \mathrm{oz}$. per head per week to about $2 \mathrm{oz}$., and of sugar from about $12 \frac{1}{2}$ to $4 \frac{1}{2} \mathrm{oz}$. The starvation of the German people was thus due more to the decision of the German Government 
to sacrifice food for war ends than to the blockade of the Allies. Then, as now, guns instead of butter was the policy. If the Allies had allowed food into Germany, the enemy would have been enabled to release a further part of the national effort from food production to war ends, or to use a greater proportion of the food available for making explosives. Lifting the blockade on food would have been almost equivalent to lifting the blockade on munitions.

It is very doubtful whether food shortage in Europe will play as important a part in this War as it did in the last. The building up of a food reserve was part of the Nazi 'military economy', established in 1934. Agriculture was organized to increase crops which give the maximum amount of food per acre and to adjust animal husbandry to give the maximum amount of human food for the feeding-stuffs consumed. The potato gives twice as much human food per acre as grain. Although Germany had a relatively large acreage of potatoes in 1939, an additional 15 per cent was asked for. This would provide roughly about six times as much potatoes per head of the population as the United Kingdom supplies. Reserves of grain and fat were built up. By April 1938, there was a reserve of 4 million tons of grain and by April 1939 the reserve increased to 7 million tons. Between 1933 and 1938, by developing homeproduction, the total supply of fat increased by 281,000 tons. But the increase was not consumed. In fact, the consumption of fat per head per annum fell from $58 \mathrm{lb}$. in 1932, before the Nazis came into power, to $55 \mathrm{lb}$. in 1937 . The additional fat had either gone into reserve or, on Goering's plan for sacrificing butter for guns, been used for the manufacture of explosives.

At the end of the four-year plan, which adjusted agriculture to military ends, Germany may well have been nearly self-supporting in food with considerable reserves. Any depletion of reserves has probably been made up by food taken from the occupied countries. It is very doubtful, therefore, whether there is any food shortage in Germany, or at least any shortage likely to interfere with the war effort.

A consideration of the food position of Germany and of the countries now occupied makes it probable that the food supplies now controlled by the Nazis are sufficient to prevent any acute shortage if they are distributed according to needs. But the Nazis are likely to use their control of food to suit military needs rather than the nutritional needs of the people. Control of food can be used as a means of keeping conquered people in subjection. Although a sudden shortage of food among a previously well-fed people might cause revolt, a gradual deterioration in the diet is more likely to be accompanied by physical weakness, loss of courage and will-power and general apathy. People suffering from malnutrition and undernutrition are easily kept in subjection.

It would be foolish to hope for a collapse of the Nazis in the near future owing to food shortage. It would be safer to assume that their present reserves will be sufficient to carry them on to the next harvest. It would be equally foolish to depend upon food shortage as a means of defeating the enemy next year or the year after. It is difficult to set limits to the extent to which food can be increased by modern agricultural science, provided there are sufficient fertilizers and labour. By exploiting to the fullest extent all the lands of Europe which they control and all the subject labour, and by arranging distribution to suit military ends, the Nazis may well be able to maintain the strength of the war machine unimpaired indefinitely.

If, as we believe, the Nazis can, by devoting sufficient effort to it, produce sufficient food to maintain the efficiency of the war machine, what is the value of the food blockade? A food blockade is a valuable part of our war effort because any food allowed into countries occupied by the Nazis enables them to withdraw an equivalent part of the effort devoted to food production to direct war ends, and to that extent increases their military efficiency. Further, although explosives are not made from food to the same extent as in the War of 1914-18, large amounts of foodstuffs are being used for making motor-spirits and for other purposes connected with the manufacture of war material. The lifting of the blockade on food would be equivalent to the return to Germany of prisoners captured or the lifting of the blockade on petrol or other war materials.

There is evidently food shortage in unoccupied France, and there may be some degree of shortage in some of the occupied countries; but to what extent it exists it is difficult to assess. Travellers' tales are notoriously unreliable, and official news from the enemy is calculated to deceive rather than to inform. It is being suggested that food might be allowed through in sufficient amounts to prevent suffering among the people of the conquered countries. Even if food were allowed in, 
there is no guarantee that the people would benefit. If the Nazis are unwilling to share the food they control with these people or even allow them to keep the food they have, it is very doubtful whether they would allow them to benefit from any food allowed in. Measures could, of course, be taken to ensure that the people received the actual food sent in, but there is nothing to prevent the Nazis, who have complete control, from withdrawing an equivalent amount of food either for the troops of occupation or for transfer to Germany. It has been suggested that dried milk and cod liver oil might be allowed in to prevent malnutrition, but the Nazis could take away an equivalent amount of dairy products.

The only way to bring relief to Europe is to defeat the Nazis and drive them out of the conquered countries. Anything which will contribute to the destruction of the Nazi war machine will contribute to the relief of the conquered people. Any food, or other material which can be used for war purposes, allowed into the part of Europe controlled by the Nazis, strengthens the Nazi war machine and, to that extent, delays the deliverance of the people of Europe. But preparations should now be made so that food and other forms of assistance may be rushed to these countries as soon as they are liberated. Attention should be given now to what foods will be most effective in rectifying the evil effects of shortage during the enemy occupation, and the organization for the transport and distribution of the food got ready.

The action which ought to be taken now and after the War should be based on facts and not on opinions formed from rumours and enemy propaganda. Until war broke out, there was an international committee of nutritional experts, including prominent American and British men of science nominated by their respective Governments. For three years before the War, this com- mittee, in collaboration with a committee of economic and agricultural experts, was engaged in studying the food position in Europe. It would be better able to assess the true position and make recommendations than any other body which could be set up. Further, it had experience of similar work in advising on food relief measures for Spain. The United States and the British Commonwealth of Nations might well appoint the American and British members of this committee, with an American chairman, to investigate the position and report on the present food position in Europe in so far as information is available, the means which ought to be taken to relieve distress arising from food shortage in Europe, and also on the economic and political measures which should be taken to base post-War world food policy on nutritional needs. In its pre-War studies, this committee found that the basing of food policy in the nutritional needs of the people would, in addition to bringing about a great reduction in disease and a rise in the standard of living, bring prosperity to agriculture and increase international trade. The committee suggested could make sound recommendations based on ascertained fact to deal with the present position, and could also make an important contribution to the building up of the new and better world order we are looking for after the War.

Every means should then be taken to let the people in Nazi-occupied Europe know that the free countries are making elaborate preparations to bring food and other forms of assistance as soon as the Nazis are defeated. The knowledge that these preparations were being made on the recommendation of a committee of scientific men, all of whose names are well-known in every country in Europe, would help them to endure the evils of their temporary bondage and encourage them, at the appropriate time, to assist in their own deliverance.

\section{TRADITION IN A NEW WORLD ORDER}

$\mathrm{W}^{\mathrm{E}}$ E live in the birth-pangs of a new world. Of what order that world will be now hangs on the arbitrament of war. Should the final decision be, as we hope and confidently expect, in favour of Great Britain and her Allies, to them will fall the task of moulding the new world in that shape which the ideals and principles for which we have taken up the challenge of dictators and totalitarian States may best be given practical effect. The burden will be heavy; and not the least onerous part of the task will be how best to ensure that in the endeavour to attain a state of permanent peace in the future by bringing about co-operation between peoples and nations in all matters which pertain to the common interests of mankind, loyalty to these principles and ideals 